\title{
PENERAPAN MODEL PEMBELAJARAN INKUIRI TERSTRUKTUR DENGAN MIND MAPPING UNTUK MENINGKATKAN HASIL BELAJAR BIOLOGI
}

\author{
Novi Puspita Sari ${ }^{*}$, Yennita ${ }^{1}$, Sri Irawati ${ }^{1}$ \\ ${ }^{1}$ Program Studi Pendidikan Biologi, Fakultas Keguruan dan Ilmu Pendidikan, Universitas Bengkulu \\ email:novipuspita83@gmail.com
}

\begin{abstract}
Abstrak
Penelitian ini bertujuan untuk mendeskripsikan aktivitas guru, peserta didik, kemampuan membuat mind mapping dan hasil belajar kognitif dengan menerapkan model pembelajaran inkuiri terstruktur dengan bantuan teknik mind mapping di kelas VIII 7 SMPN 04 Kota Bengkulu. Jenis penelitian ini adalah penelitian tindakan kelas, dilakukan dalam dua siklus dengan setiap siklusnya terdiri atas 4 tahapan yaitu: tahap perencanaan, pelaksanaan tindakan, pengamatan dan refleksi. Subyek penelitian ini adalah guru dan peserta didik kelas VIII 7 SMPN 04 Kota Bengkulu tahun ajaran 2017/2018, yang terdiri dari 35 peserta didik. Instrumen penelitian yang digunakan adalah lembar observasi, lembar penilaian mind mapping dan lembar tes. Hasil penelitian dari analisa data observasi guru siklus I diperoleh skor rata-rata 26 (baik), siklus II menjadi 30 (baik). Hasil analisis data observasi peserta didik siklus I diperoleh skor rata-rata 24 (baik), siklus II menjadi 30 (baik). Hasil analisis data penilaian kemampuan membuat mind mapping siklus I dan II yaitu nilai 65\% (baik) dan siklus II menjadi $80 \%$ (baik). Hasil belajar ranah kognitif siklus I 65,71\% (baik) menjadi siklus II 85,71\% (baik). Dari hasil penelitian disimpulkan bahwa model pembelajaran Inkuiri terstruktur dengan bantuan teknik mind mapping dapat meningkatkan hasil belajar peserta didik kelas VIII ${ }_{7}$ SMPN 04 Kota Bengkulu.
\end{abstract}

Kata kunci: Hasil Belajar, Inkuiri Terstruktur, Mind Mapping.

\begin{abstract}
This study aims to describe teaching activities, learning activities, ability to make mind mapping and students' learning outcome by implementation of structured inquiry model at VIII 7 class of SMPN 04 Kota Bengkulu on the material of human excretion system. Type of this research was a classroom action research that was conducted in two cycles and each cycle consists of four stages: planning, implementation of action, observation, and reflection. The subjects of the study were teachers and students at VIII 7 class of SMPN 04 Kota Bengkulu in academic year 2017/2018, which was consisted of 35 students. The research instrument was used observation sheet, mind mapping assessment sheet and test sheet. The results of the teachers' observation data analysis in cycle I obtained an average score of 26 (good), cycle II to 30 (good). The result of data observation analysis of learning activities, cycle I obtained an average score of 24 (good), cycle II to 30 (good). The result of data observation analysis of students' ability to make mind mapping, cycle I obtained an persentage score of $65 \%$ (good), cycle II to $80 \%$ (good). Then, the learning result of cognitive aspect of cycle I got $65,71 \%$, cycle II to $85,71 \% \%$. As the conclusion of this study, that Structured inquiry learning model with mind mapping tehnique could improve students' learning outcome at $\mathrm{VIII}_{7}$ class of SMPN 04 Bengkulu city.
\end{abstract}

Keywords: Mind Mapping, Learning Outcome, Inquiry Learning. 


\section{PENDAHULUAN}

Pendidikan dapat diselenggarakan melalui berbagai lembaga pendidikan. Salah satu bentuk lembaga pendidikan formal adalah sekolah. Lulusan pada setiap jenjang sekolah harus memenuhi standar kompetensi lulusan yang telah ditetapkan sebagai bentuk tercapainya keberhasilan pendidikan. Keberhasilan pendidikan dipengaruhi oleh perubahan dan pembaharuan atas segala komponen pendidikan seperti sarana dan prasarana, dana, kurikulum, tenaga pendidik, desain pembelajaran seperti model maupun metode dan kurikulum (Suardi, 2012).

Kurikulum yang diterapkan di Indonesia pada saat ini yaitu kurikulum 2013. Kurikulum 2013 menekankan penerapan pendekatan ilmiah pada proses pembelajaran. Pendekatan ilmiah melibatkan peserta didik dalam penyelidikan dan interaksi peserta didik dengan guru maupun peserta didik lainnya. Peserta didik diarahkan untuk mengembangkan kemampuan berpikir, bernalar dan bekerja ilmiah dengan pengalaman belajar. Pengalaman yang paling tinggi nilainya adalah direct purposeful experience, yaitu pengalaman yang diperoleh dari hasil kontak langsung dengan lingkungan, objek, binatang, dan sebagainya (Zubaidah dkk., 2017).

Berdasarkan hasil observasi materi gerak pada makhluk hidup yang dilakukan saat kegiatan magang 3 di kelas $\mathrm{VIII}_{7} \mathrm{SMPN}$ 04 Kota Bengkulu diperoleh informasi sebagai berikut: 1) proses pembelajaran bersifat teacher centered; 2) Variasi penggunaan model pembelajaran sesuai karakteristik materi ajar masih kurang; 3 ) Peserta didik kurang berpartisipasi aktif dalam proses pembelajaran; 4) Peserta didik belum mengetahui teknik mencatat yang efektif; 5) Peserta didik kurang memahami materi yang diberikan guru, terlihat dari hasil belajar ulangan harian mata pelajaran IPA Biologi hanya 16 dari 35 peserta didik yang mendapat kategori tuntas. Kriteria Ketuntasan Minimal (KKM) di SMPN 04 Kota Bengkulu yaitu $\geq 75$ dengan ketuntasan belajar klasikal $\geq 75 \%$. Hal ini berarti hanya $45,71 \%$ peserta didik kelas $\mathrm{VIII}_{7}$ yang tuntas secara klasikal.

Berdasarkan permasalahan di atas, perlu adanya pembaharuan dalam proses pembelajaran untuk dapat meningkatkan hasil belajar. Salah satu komponen yang dipandang mempunyai peran strategis dalam upaya mendongkrak keberhasilan proses pembelajaran yaitu model pembelajaran. Salah satu model pembelajaran yang sejalan dengan implementasi Kurikulum 2013 dan pembelajaran IPA yaitu model pembelajaran inkuiri.

Model pembelajaran inkuiri sesuai dengan perkembangan psikologi belajar modern yang menganggap belajar adalah proses perubahan tingkah laku karena adanya pengalaman (Nurdin dkk., 2016). Peserta didik dalam kelompoknya secara aktif mencari informasi baru berdasarkan informasi yang diketahui sebelumnya dengan bimbingan guru. Peserta tidak lagi menjadi penerima pasif melainkan lebih aktif terlibat dalam pembelajaran hingga menemukan sendiri konsep atau pengetahuan baru dengan pengalaman belajar langsung. Pengetahuan tersebut diharapkan lebih bertahan lama dan bisa meningkatkan hasil belajar peserta didik.

Model pembelajaran inkuiri dibagi ke dalam empat tingkatan, yaitu inkuiri konfirmasi, terstruktur, terbimbing dan terbuka. Pada penelitian ini dipilih model pembelajaran inkuiri terstruktur, karena model pembelajaran inkuiri belum sesuai digunakan ketika peserta didik belum memiliki pengalaman dalam belajar dengan menggunakan model inkuiri. Model pembelajaran inkuiri terstruktur menuntut guru untuk dapat memberikan bimbingan dalam setiap tahap inkuiri 
sehingga mampu memfasilitasi siswa dalam menguasai aspek proses dan produk pembelajaran. Inkuiri terstruktur dapat memberdayakan keterampilan proses sains, rasa percaya diri, kemampuan berpikir, pemahaman dan hasil belajar siswa (Ritonga, 2018; Hartati, 2015). Inkuiri terstruktur juga dikatakan sebagai inkuiri tingkat rendah yang umumnya diterapkan di pendidikan tingkat dasar (SD dan SMP). Jenis inkuiri ini penting karena memungkinkan siswa secara bertahap mengembangkan kemampuan melakukan inkuiri ke jenjang yang lebih tinggi (Zubaidah dkk., 2017).

Pembelajaran inkuiri dapat dipadukan dengan metode lainnya untuk mendapatkan hasil yang lebih efektif. Salah satu perpaduan yang dapat dilakukan yaitu memanfaatkan mind map sebagai media pembelajaran dalam model inkuiri. Mind mapping merupakan cara mencatat yang kreatif, efektif, mudah dan berdaya guna bagi setiap peserta didik untuk menghasilkan gagasan, mencatat apa yang dipelajari atau merencanakan tugas baru. Nurdin dkk., (2016) mengungkapkan bahwa Teknik mind mapping bertujuan untuk mengoptimalkan fungsi otak sehingga dapat memfokuskan materi dalam belajar dan diharapkan dapat meningkatkan hasil belajarnya.

Berdasarkan latar belakang di atas, peneliti dan guru biologi sepakat untuk melakukan perbaikan pembelajaran di kelas VIII 7 SMPN 04 Kota Bengkulu melalui penerapan model pembelajaran inkuiri terstruktur dengan bantuan teknik mind mapping pada materi sistem ekskresi manusia untuk meningkatkan hasil belajar peserta didik.

\section{METODE}

Jenis penelitian yang digunakan yaitu penelitian tindakan kelas. Metode yang digunakan adalah metode deskriptif. Metode deskriptif digunakan untuk memperoleh deskripsi aktivitas guru dan peserta didik, kemampuan membuat mind mapping serta hasil belajar peserta didik melalui penerapkan model pembelajaran inkuiri terstruktur dengan bantuan teknik mind mapping di Kelas $\mathrm{VIII}_{7} \mathrm{SMPN} 04$ Kota Bengkulu. Subyek penelitian ini adalah guru dan seluruh peserta didik kelas $\mathrm{VIII}_{7}$ SMPN 04 Kota Bengkulu dengan jumlah 35 peserta didik.

Instrumen penelitian yang digunakan yaitu lembar observasi, lembar penilaian mind mapping, dan lembar tes. Lembar observasi dalam digunakan untuk mengamati aktivitas guru dan peserta didik. Lembar penilaian mind mapping dalam digunakan untuk mengetahui kemampuan peserta didik membuat mind mapping. Lembar tes digunakan untuk memperoleh data tentang hasil belajar kognitif peserta didik.

Teknik analisis data. Data hasil observasi aktivitas mengajar guru dan belajar peserta didik diolah secara deskriptif dengan cara mencari rata-rata dan rentang kategori. Rumus rata-rata adalah sebagai berikut :

$$
\bar{X}=\frac{\sum X}{N} \text { (Sukardi, 2012) }
$$

Keterangan :

$X=$ Rata - rata

$\Sigma \mathrm{X}=$ Jumlah seluruh skor yang diperoleh

$\mathrm{N}=$ Jumlah observer

Penentuan kisaran skor setiap kategori diolah dengan menggunakan rumus berikut:

Rentang kategori $=\frac{\text { skor tertinggi-skor terendah }}{\text { jumlah } \text { kategori }}$

(Sukardi, 2012)

Keterangan:

Skor tertinggi $=$ jumlah butir pengamatan $X$ skor tertinggi setiap butir

Skor terendah = jumlah butir pengamatan $\mathrm{x}$ skor terendah setiap butir

Mind mapping yang dibuat peserta didik dinilai menggunakan rumus: 
$\%$ Nilai $=\frac{\text { Jumlah skor yang diperoleh }}{\text { Skor } \text { Total }} \times 100 \%$

(Zein, 2015)

Menurut Zein (2015) nilai yang diperoleh kemudian diinterpretasikan ke kriteria tingkat kelayakan mind mapping yaitu Baik sekali (81-100\%), Baik (61-80\%), Cukup (41-60\%), kurang (21-40\%), Kurang sekali $(<21 \%)$.

Data hasil tes peserta didik diolah secara deskriptif dengan rumus presentase ketuntasan belajar klasikal sebagai berikut: $K B=\frac{N S}{N} \times 100 \%$ (Sudijono, 2014) Keterangan:

$\mathrm{KB}=$ Persentase ketuntasan belajar

$\mathrm{N} \quad=$ Jumlah peserta didik

NS =Jumlah peserta didik yang mendapatkan nilai $\geq 75$ (Ketentuan SMPN 04 Kota Bengkulu).

\section{HASIL DAN PEMBAHASAN}

Berdasarkan hasil analisis data penelitian yang telah dilakukan di kelas $\mathrm{VIII}_{7}$ SMPN 04 Kota Bengkulu berupa penerapan model pembelajaran inkuiri terstruktur dengan bantuan teknik mind mapping untuk meningkatkan hasil belajar biologi diperoleh hasil sebagai berikut:

Aktivitas guru dan peserta didik mengalami peningkatan dari siklus I ke siklus II dapat dilihat pada Tabel 1.

Tabel 1. Data Aktivitas Guru dan Peserta Didik di Siklus I dan II

\begin{tabular}{ccccc}
\hline \multirow{2}{*}{ Aktivitas } & \multicolumn{2}{c}{ Siklus I } & \multicolumn{2}{c}{ Siklus II } \\
\cline { 2 - 5 } & $\begin{array}{c}\text { Rata- } \\
\text { rata }\end{array}$ & Kriteria & $\begin{array}{c}\text { Rata- } \\
\text { Rata }\end{array}$ & Kriteria \\
\hline $\begin{array}{c}\text { Guru } \\
\text { Peserta } \\
\text { Didik }\end{array}$ & 26 & Baik & 30 & Baik \\
\hline
\end{tabular}

Berdasarkan Tabel 1. dapat dilihat bahwa pada siklus I skor rata-rata aktivitas guru yaitu 26 dengan kriteria baik kemudian pada siklus II skor rata-rata yang diperoleh meningkat menjadi 30 dengan kriteria baik. Sedangkan skor rata-rata aktivitas peserta didik yaitu 24 dengan kriteria baik kemudian pada siklus II skor rata-rata yang diperoleh meningkat menjadi 30 dengan kriteria baik.

Adapun butir pengamatan aktivitas guru yang dinilai cukup oleh observer yaitu bu tir pengamatan guru membimbing peserta didik merumuskan hipotesis, guru membimbing peserta didik untuk mengumpulkan data, guru membimbing peserta didik membuat mind mapping, guru membimbing peserta didik untuk menguji hipotesis. Sedangkan butir pengamatan aktivitas peserta didik yang dinilai cukup oleh observer yaitu peserta didik memperhatikan apersepsi dan motivasi, memperhatikan guru menyampaikan tujuan pembelajaran, membuat hipotesis, mengumpulkan data, bekerja sama membuat mind mapping dan menguji hipotesis.

Pada tahap guru membimbing peserta didik merumuskan masalah dilakukan perbaikan pembelajaran di siklus II. Perbaikan dilakukan pada sintaks merumuskan masalah dilakukan dengan memberikan kesempatan kepada peserta didik untuk membuat pertanyaan terkait dengan fenomena. Hasil perbaikan yang telah dilakukan yaitu guru mampu membimbing 6 kelompok dengan optimal dan mengajukan pertanyaan terkait alasan peserta didik merumuskan hipotesis. Alasan ini berfungsi sebagai landasan berpikir agar hipotesis yang dibuat bukan hanya perkiraan semata tetapi bersifat rasional dan logis. Hal ini selaras dengan apa yang dikemukakan oleh Trianto (2014) bahwa hipotesis adalah jawaban sementara atas pertanyaan atau solusi permasalahan yang dapat diuji dengan data. Hipotesis digunakan untuk menuntun proses pengumpulan data sehingga harus dibuat berdasarkan landasan berpikir yang logis.

Pada tahap membimbing peserta didik mengumpulkan data dan membuat mind mapping, setelah dilakukan 
perbaikan pembelajaran di siklus II guru mampu melakukan pengelolaan kelas lebih baik dengan membagi perhatian dalam membimbing setiap kelompok. Hal ini dilakukan guru dengan melihat aktivitas atau kegiatan peserta didik pada setiap kelompok dan membimbing kelompok yang mengalami kesulitan dengan memberikan penjelasan. Hal ini selaras dengan pernyataan yang dikemukakan Majid (2014) bahwa pengelolaan kelas yang efektif dapat terjadi jika guru mampu membagi perhatian kepada beberapa kegiatan dalam waktu yang sama dengan cara: 1) Visual; dan 2) Verbal.

Pada tahap menguji hipotesis, setelah dilakukan perbaikan disiklus II guru mampu memberikan penekanan lebih lanjut seperti bertanya "Apa landasan dari hipotesis yang diajukan?" dan "Apakah hasil kegiatan praktikum yang kalian lakukan mendukung hipotesis yang dibuat di awal pembelajaran?". Penekanan ini penting agar peserta didik memiliki keyakinan yang kuat terhadap kebenaran hipotesisnya. Hal ini selaras dengan pernyataan yang disampaikan Majid (2014) yang menyatakan bahwa penekanan dapat membantu guru memusatkan perhatian peserta didik kepada pokok masalah dan mengurangi informasi yang tidak penting. Sehingga peserta didik memiliki keyakinan terhadap kebenaran jawaban yang didukung oleh data percobaan dan dapat dipertanggungjawabkan.

Pada tahap peserta didik memperhatikan apersepsi dan motivasi, peserta didik masih ragu-ragu dalam menjawab pertanyaan. Oleh karena itu, di siklus II guru lebih mendorong peserta didik percaya diri dalam menjawab pertanyaan. Hal tersebut dilakukan guru dengan memberi penguatan, misalnya memberi pujian jika peserta didik dapat menjawab pertanyaan dengan benar. Hal ini selaras dengan yang dikemukakan
Setiawati dkk (2018) bahwa pada umumnya ganjalan atau imbalan akan membawa dampak positif baik bagi orang yang bersangkutan maupun bagi orang lain yang mengetahuinya.

Pada tahap peserta didik memperhatikan guru menyampaikan tujuan pembelajaran di siklus I, peserta didik dalam kelompoknya masih terlihat sibuk sendiri. Oleh karena itu, di siklus II guru lebih mengkondisikan kelas dengan menanggapi dan menegur peserta didik yang masih kurang konsentrasi atau terlihat sibuk sendiri pada saat proses pembelajaran. Hal ini selaras dengan yang dikemukakan Majid (2014) salah satu komponen keterampilan mengelola kelas yaitu menegur. Apabila terjadi penyimpangan tingkah laku peserta didik yang mengganggu proses pembelajaran, guru hendaknya memberikan teguran.

Hasil pengamatan aktivitas belajar peserta didik pada tahap merumuskan hipotesis, mengumpulkan data, membuat mind mapping dan menguji hipotesis di siklus I belum berjalan optimal. Tidak semua peserta didik di dalam kelompoknya bekerjasama merumuskan hipotesis. Pada siklus II, guru memusatkan perhatian kelompok dengan cara menginstruksikan peserta didik untuk membagi tugasnya dalam kelompok. Hal ini selaras dengan yang dikemukakan Majid (2014) bahwa kegiatan siswa dalam belajar dapat dipertahankan jika guru memusatkan perhatian siswa untuk melakukan tugas secara berkelompok atau bekerja sama.

Butir pengamatan yang dinilai cukup oleh observer pada siklus I sudah dinilai baik di siklus II. Perbaikan butir pengamatan aktivitas guru dan peserta didik dilakukan untuk meningkatkan kegiatan pembelajaran dan sebagai upaya untuk meningkatkan hasil belajar.

Pada penelitian ini terdapat 4 aspek penilaian kemampuan membuat mind mapping yaitu struktur umum, desain, kata 
kunci dan isi (Evrekli dkk., 2010). Adapun hasil kemampuan peserta didik membuat mind mapping dapat dilihat pada Tabel 2.

Tabel 2. Data Hasil Kemampuan Peserta Didik Membuat Mind Mapping

\begin{tabular}{ccccccc}
\hline & \multicolumn{4}{c}{ Aspek Penilaian } & Skor & Krite \\
\cline { 2 - 5 } & $\begin{array}{c}\text { Struktur } \\
\text { umum }\end{array}$ & Desain & $\begin{array}{c}\text { Kata } \\
\text { kunci }\end{array}$ & Isi & total & -ria \\
\hline $\begin{array}{c}\text { Nilai } \\
\text { Siklus } \\
\text { I }\end{array}$ & 9 & 9 & 17 & 12 & 47 & \\
$\begin{array}{c}\text { Nilai } \\
\text { Siklus } \\
\text { II }\end{array}$ & 12 & 15 & 17 & 14 & 58 & \\
\hline
\end{tabular}

Berdasarkan Tabel 2. dapat dilihat bahwa pada siklus I persentase nilai skor total kelompok yang diperoleh yaitu $65 \%$ dengan kriteria baik kemudian pada siklus II persentase nilaiskor total kelompok meningkat menjadi $80 \%$ dengan kriteria baik.

Adapun butir pengamatan yang dinilai cukup oleh observer yaitu aspek penilaian struktur umum dan desain (warna dan gambar). Setelah dilakukan perbaikan di siklus II, terjadi peningkatan kemampuan peserta didik disetiap kelompoknya dalam membuat mind mapping. Peserta didik sudah memahami penggunaan teknik mind mapping sebagai teknik mencatat sehingga pembuatan mind mapping memberikan hasil yang lebih maksimal karena telah dilakukan berulang. Hasil mind mapping peserta didik sudah menggunakan garis lengkung, kombinasi warna dan sudah menggunakan gambar atau simbol. Hal ini selaras dengan pernyataan Sari dkk., (2015) dalam penelitiannya bahwa perubahan perilaku siswa akan memberikan hasil yang maksimal jika perilaku itu dilaksanakan secara berulang atau berkelanjutan.

Berdasarkan pembelajaran yang telah dilakukan melalui penerapan model pembelajaran inkuiri terstruktur dengan bantuan teknik mind mapping pada siklus I dan II diperoleh data hasil belajar kognitif peserta didik yang ditunjukkan pada Tabel 3.

Tabel 3. Data Hasil Belajar Kognitif Peserta Didik

\begin{tabular}{lcc}
\multicolumn{2}{c}{ Siklus } \\
\cline { 2 - 3 } & \multicolumn{2}{c}{ Siklus } \\
\cline { 2 - 3 } & $\mathbf{~ I}$ & II \\
\hline $\begin{array}{l}\text { Nilai Rata-rata } \\
\text { Persentase } \\
\text { ketuntasan belajar } \\
\text { klasikal }\end{array}$ & $65,71 \%$ & $85,71 \%$ \\
Kriteria & $\begin{array}{l}\text { Belum } \\
\text { Tuntas }\end{array}$ & Tuntas \\
\hline
\end{tabular}

Peningkatan persentase ketuntasan belajar klasikal dari siklus I ke siklus II menunjukkan bahwa penerapan model pembelajaran inkuiri terstruktur dapat meningkatkan hasil belajar. Model pembelajaran inkuiri melibatkan peserta didik secara aktif dalam kegiatan belajar melalui penyelidikan. Penemuan dan keterlibatan langsung peserta didik dalam proses pembelajaran menjadi faktor yang mendorong peningkatan hasil belajar kognitif peserta didik. Hal ini selaras dengan hasil penelitian yang pernah dilakukan sebelumnya oleh Afni (2015) dimana ia menyatakan bahwa model pembelajaran inkuiri sangat baik diterapkan pada materi sistem ekskresi karena model pembelajaran inkuiri mempunyai kelebihan yang dapat menekankan kepada pengembangan aspek kognitif dan dapat mengikutsertakan seluruh peserta didik terlibat secara aktif dalam menemukan konsep pelajaran.

Penerapan model pembelajaran inkuiri terstruktur ini lebih bermakna dengan kombinasi penggunaan teknik mind mapping sebagai teknik mencatat. Penggunaan teknik mind mapping memudahkan peserta didik dalam merangkum materi pembelajaran ke dalam satu halaman sehingga lebih memudahkan untuk mereview ulang materi. Peserta didik dapat membuat catatan berwarna yang menarik berupa tulisan, simbol atau gambar yang saling terhubung sehingga lebih memudahkan otak untuk mengingat dan memahami materi tersebut. Hal ini selaras dengan yang dikemukakan Nugroho (2012) bahwa 
mind mapping adalah teknik mencatat menggunakan pemetaan gambar. Keterlibatan otak akan memudahkan untuk mengatur dan mengingat segala informasi dengan menggunakan kombinasi warna, simbol, bentuk yang akan memudahkan otak menyerap informasi yang diterima.

Proses belajar mengajar oleh peserta didik dan guru merupakan salah satu faktor yang mempengaruhi hasil belajar. Peningkatan aktivitas guru dapat mendorong peserta didik untuk ikut terlibat aktif dalam proses pembelajaran dan berpengaruh positif terhadap hasil belajar peserta didik. Hal ini sejalan dengan yang dikemukakan Dimyati dkk (2013) bahwa hasil belajar merupakan hasil dari suatu interaksi tindak belajar dan tindak mengajar. Dengan belajar maka kemampuan mental peserta didik akan semakin meningkat. Seniwati (2010), aktivitas dalam proses pembelajaran mempunyai peranan yang sangat penting. Aktivitas belajar adalah segenap rangkaian secara sadar yang dilakukan seseorang yang mengakibatkan perubahan dalam dirinya. Peningkatan aktivitas belajar mengajar dengan penggunan model pembelajaran inkuiri memberikan kontribusi positif terhadap peningkatan hasil belajar.

Hasil penelitian dari siklus I ke siklus II, menunjukkan adanya peningkatan persentase ketuntasan belajar klasikal peserta didik sebesar 20\%. Hal ini menunjukkan bahwa penerapan model pembelajaran inkuiri tersetruktur berbantuan teknik mind mapping dapat meningkatkan hasil belajar peserta didik. $\mathrm{Hal}$ ini selaras dengan penelitian Ferlina (2012) yang menyatakan bahwa penerapan model pembelajaran guided inquiry dengan teknik mind mapping dapat meningkatkan aktivitas dan ketuntasan hasil belajar siswa.

\section{PENUTUP}

\section{Simpulan}

Berdasarkan Penelitian Tindakan Kelas di Kelas VIII 7 SMPN 04 Kota Bengkulu melalui penerapan Model Pembelajaran Inkuiri Terstruktur dengan bantuan teknik Mind Mapping pada materi Sistem Ekskresi pada Manusia dapat disimpulkan bahwa perbaikan pembelajaran melalui penerapan model pembelajaran inkuiri terstruktur dengan bantuan teknik mind mapping dalam proses pembelajaran IPA Biologi materi sistem ekskresi dapat meningkatkan aktivitas mengajar guru dan aktivitas belajar peserta didik Kelas $\mathrm{VIII}_{7}$ SMPN 04 Kota Bengkulu. Selain itu, Kemampuan peserta didik dalam membuat mind mapping secara keseluruhan meningkat, yaitu dari persentase nilai $65 \%$ dengan kriteria baik menjadi $80 \%$ dengan kriteria baik serta perbaikan pembelajaran melalui penerapan model pembelajaran inkuiri terstruktur dengan bantuan teknik mind mapping dalam proses pembelajaran IPA biologi materi sistem ekskresi dapat meningkatkan hasil belajar peserta didik Kelas $\mathrm{VIII}_{7}$ SMPN 04 Kota Bengkulu yaitu dengan persentase ketuntasan belajar klasikal dari $65,71 \%$ menjadi $85,71 \%$.

\section{Saran}

Berdasarkan penelitian yang telah dilakukan, beberapa saran yang dapat dianjurkan yaitu

1. Diharapkan kepada guru mata pelajaran IPA Biologi kelas VIII7 SMPN 04 Kota Bengkulu dapat menggunakan model pembelajaran inkuiri terstruktur dengan bantuan teknik mind mapping sebagai salah satu alternatif untuk diterapkan dalam pembelajaran IPA Biologi materi sistem ekskresi manusia sebagai salah satu upaya meningkatkan hasil belajar peserta didik.

2. Diharapkan untuk peneliti selanjutnya, dalam pembuatan mind mapping 
diperlukan pengawasan guru yang lebih optimal. Selain itu, peneliti diharapkan dapat menyesuaikan alokasi waktu pembelajaran dengan setiap tahapan pembelajaran agar setiap tahapan dapat terlaksana dengan optimal.

\section{DAFTAR PUSTAKA}

Afni, R.T., (2015). Penerapan Model Pembelajaran Inkuiri Pada Materi Sistem Ekskresi Manusia untuk Meningkatkan Hasil Belajar IPA Biologi Siswa Kelas VIIIA SMPN 11 Kota Bengkulu. Skripsi Tidak Diterbitkan. Bengkulu: FKIP UNIB.

Dimyati \& Mudjiono. (2013). Belajar dan Pembelajaran. Jakarta: Rineka Cipta.

Evrekli, E., \& Gunay, A. (2009). Mind mapping applications in special teaching methods courses for science teacher candidates and teacher candidates' opinions concerning the applications, 1(1), 2274-2279.

http://doi.org/10.1016/j.sbspro.20 09.01.400

Ferlina, O. (2012). Penerapan Model Pembelajaran Guided Inquiry dengan Teknik Mind Mapping untuk Meningkatkan Aktivitas dan Ketuntasan Hasil Belajar Biologi Siswa Kelas VII.2 Tahun Ajaran 2011/2012 SMP Negeri 1 Srono Banyuwangi. Skripsi Tidak Diterbitkan. Jember: Universitas Negeri Jember.

Hartati, T. A. W., Corebema, A. D., Suwono, H. (2015). Perbandingan Potensi Model Pembelajaran Berbasis Kosntruktivis (Inkuiri Terstruktur dan Siklus Belajar 5e) dalam Memberdayakan Keterampilan Proses Sains dan Hasil Belajar Kognitif SiswaBerkemampuan
Akademik Rendah. Seminar Nasional XII Pendidikan Biologi FKIP UNS 2015.

Majid, A. (2014). Strategi Pembelajaran. Bandung: PT Remaja Rosdakarya.

Nugroho, P.A. (2012). Penerapan Guided Inquiry Disertai Mind Mapping Untuk Meningkatkan Motivasi Dan Hasil Belajar Biologi Peserta didik SMA Negeri 1 Ngemplak Boyolali Tahun Pelajaran 2011/2012. Skripsi. Surakarta: Fakultas Keguruan dan Ilmu Pendidikan. Universitas Sebelas Maret Surakarta.

Nurdin, S., \& Adriantoni. (2016). Kurikulum dan Pembelajaran. Jakarta: Rajawali Press.

Sari, F.N. (2015). Penggunaan Peta Pikiran (Mind mapping) sebagai Instrumen Penilaian Kreativitas Mahasiswa Calon Guru Biologi Pada Matakuliah Metodologi Penelitian Berbasis Lesson Study. Makalah disajikan dalam Seminar Nasional Pendidikan dan Saintek 2016. Universitas Muhammadiyah Surakarta, Surakarta ,21 Mei.

Seniwati. (2010). Peningkatan Aktivitas, Sikap dan Hasil Belajar Biologi Melalui Penerapan Model Pembelajaran Inkuiri pada Siswa Kelas $X_{1}$ SMA Negeri 1 Bontonompo. Jurnal Nalar Pendidikan., 3 (1): 317-321.

Setiawati, R. \& Jamal, A. (2018). Kiat-kiat Menjadi Guru Pemulayang Hebat. Yogyakarta: Deepublish.

Suardi. (2012). Pengantar Pendidikan Teori dan Aplikasi. Jakarta: PT Indeks.

Sudijono, A. (2014). Pengantar Statistika Pendidikan. Jakarta: Rajawali Pers. 
Sukardi. (2012). Evaluasi Pendidikan Prinsip \& Operasionalnya. Jakarta: Bumi Aksara.

Trianto. (2014). Mendesain Model Pembelajaran Inovatif, Progresif dan Kontekstual: Konsep, Landasan, dan implementasinya pada Kurikulum 2013 (Kurikulum Tematik Integratif/KTI). Jakarta: Prenadamedia Group.

Zein, A. (2015). Penggunaan Mind Map Dalam Meningkatkan Aktivitas dan Hasil Belajar Mahasiswa pada Mata Kuliah Biologi Umum di FMIPA Universitas Negeri Padang. Prosiding Semirata 2015 bidang MIPA BKS-PTN Barat Universitas Tanjungpura Pontianak. Hal $482-491$.

Zubaidah, S., Susriyati, M., \& Lia Y. (2017). Buku Guru Ilmu Pengetahuan Alam. Jakarta: Kementrian Pendidikan dan Kebudayaan. 